\title{
24. RACEMIZATION OF ISOLEUCINE IN CORES FROM LEG 15 SITE 148
}

\author{
Jeffrey L. Bada, Scripps Intitution of Oceanography, La Jolla, California \\ and \\ Eugene H. Man, University of Miami, Miami, Florida ${ }^{1}$
}

\section{INTRODUCTION}

L-isoleucine, an amino acid found in the proteins of living organisms, undergoes a slow reversible conversion to the non-protein amino acid D-alloisoleucine (Bada, 1971). The reaction is termed racemization and involves a change in configuration about the asymmetric $\alpha$-carbon atom of the amino acid. (In the special case of L-isoleucine, both the $\alpha$ - and $\beta$-carbons are asymmetric and the process is called "epimerization", but for simplicity, we will refer to the reaction as racemization).

The racemization of isoleucine takes place in deep-sea sediments, and the amount of racemization can be used within certain limitations to estimate the age of the sediment (Bada et al., 1970; Wehmiller and Hare, 1971; Bada and Schroeder, 1972). The reaction has also been applied to the dating of fossil bones (Turekian and Bada 1972; Bada, 1972). Comparisons of the racemization rates of isoleucine in aqueous buffered solutions (Bada, 1971) with cores whose chronology was established by other methods (Wehmiller and Hare, 1971), demonstrated that in sediments, the interconversion of isoleucine and alloisoleucine does not follow simple reversible first-order kinetics predicted from the laboratory studies. Nonlinear first-order kinetics were also observed in elevated-temperature studies of the reaction in calcareous sediments (Bada and Schroeder, 1972). Fractional analysis of amino acids in three sediment sections of differing age (Bada and Schroeder, 1972) have shown that the reason the racemization reaction in sediments does not follow simple reversible first-order kinetics is that the sediments contain amino acids in various forms (i.e., protein, peptide, and "free" amino acids) and the isoleucine in these various fractions is racemized at widely different rates. In recent sediments, the bulk of the amino acids are in the form of proteins, but sediments several million years old contain only small amounts of proteins together with relatively larger amounts of free amino acids. The free amino acids are formed by the hydrolytic breakdown of proteins and intermediate peptides.

This report presents the results of an investigation of the racemization of L-isoleucine (iso) to D-alloisoleucine (alleu) in an approximately 250-meter continuous core from Site 148 of Leg 15. Nineteen carefully processed samples, collected as part of the Organic Geochemistry Program of the Deep Sea Drilling Project, were utilized. This study represents the most detailed amino acid analysis of any DSDP core, although there has been a report on the amino

\footnotetext{
${ }^{1}$ Visiting Investigator, Scripps Institution of Oceanography 1971-72; on leave from the University of Miami.
}

acid content of samples from Legs 5, 6, 7, and 9 (Wehmiller and Hare, 1972). The samples analyzed are summarized in Table 1.

\section{EXPERIMENTAL METHODOLOGY}

The separation of the amino acids into the various fractions was accomplished by following the procedure of Bada and Schroeder (1972). The general procedure used was as follows. Extraction of the sediment by several portions of hydrochloric acid at room temperature yielded the free amino acids and soluble peptides; when the room-temperature extracts were refluxed twenty-four hours in $6 \mathrm{M} \mathrm{HC1}$, the peptide fraction was hydrolyzed to its component amino acids. The insoluble residue remaining after the $\mathrm{HCl}$ extraction contained proteins and peptides which are insoluble in $\mathrm{HC} 1$, and amino acids from the organic detrital and clay mineral phases of the sediment. The proteins and peptides associated with the insoluble residue were subsequently hydrolyzed by refluxing in $6 \mathrm{M}$ $\mathrm{HC} 1$.

In addition to the three fractions described above, the alleu/iso ratios in the total sediment fractions were determined by acid hydrolysis of the bulk sediment. Also, the alleu/iso ratios were determined for the sonically cleaned foraminiferal fraction.

Reagents were carefully purified to remove traces of contamination. Deionized water was doubly distilled in glass apparatus; reagent grade hydrochloric acid was doubly distilled; and ammonium hydroxide was prepared by distilling gaseous ammonia into doubly distilled water under reduced pressure. Desalting was accomplished on columns of Dowex AG 50W-X8 resin regenerated by treatment with 1.5 to $2.0 \mathrm{M} \mathrm{NaOH}$ and 1.5 to $2.0 \mathrm{M} \mathrm{HC} 1$. Analyses were carried out on a Beckman-Spinco Model 118 automatic amino acid analyzer. All glassware was cleaned with chromic acid-sulfuric acid and washed with deionized and doubly distilled water.

The detailed procedures used for isolating the various fractions were as follows:

Free amino acids. Approximately 50 grams of wet sediment (maintained frozen since collection of the core) were extracted with four $50-\mathrm{ml}$ portions of $6 \mathrm{M} \mathrm{HC1}$ at room temperature, using a magnetic stirrer to agitate the mixture. After each extraction the slurry was centrifuged to separate the residue from the acid extract.

Hydrolyzed fraction. One-half of the $\mathrm{HCl}$ extract obtained as described above was refluxed for twenty-four hours in $6 \mathrm{M} \mathrm{HC1}$.

Residue fraction. The solid residues remaining after centrifuging the $\mathrm{HCl}$ extractions were hydrolyzed by refluxing twenty-four hours in $100 \mathrm{ml}$ of $6 \mathrm{M} \mathrm{HCl}$. The residue was again separated by centrifuging; the $\mathrm{HCl}$ 
TABLE 1

Samples Analyzed-Deep Sea Drilling Project Leg 15, Site 148

\begin{tabular}{|c|c|c|c|c|c|c|c|c|c|}
\hline \multirow[b]{2}{*}{ Core } & \multirow[b]{2}{*}{ Section } & \multirow{2}{*}{$\begin{array}{c}\text { Sample } \\
\text { Interval } \\
(\mathrm{cm})\end{array}$} & \multirow[b]{2}{*}{$\begin{array}{l}\text { Depth } \\
\text { (m) }\end{array}$} & \multirow[b]{2}{*}{$\underset{\%}{\mathrm{CaCO}_{3}}$} & \multicolumn{5}{|c|}{ Fractions Analyzed } \\
\hline & & & & & $\begin{array}{l}\text { Free } \\
\text { Acid }\end{array}$ & $\begin{array}{l}\text { Hydrolized } \\
\text { Fraction }\end{array}$ & $\begin{array}{l}\text { Residue } \\
\text { Fraction }\end{array}$ & $\begin{array}{c}\text { Total } \\
\text { Sediment }\end{array}$ & $\begin{array}{c}\text { Foraminifera } \\
\text { Fraction }\end{array}$ \\
\hline 1 & 2 & $90-105$ & $2.40-2.55$ & 33.2 & $\mathrm{X}$ & $\mathrm{X}$ & $\mathrm{X}$ & $\mathrm{X}$ & $\mathrm{X}$ \\
\hline 2 & 1 & $90-105$ & $9.90-10.05$ & 41.6 & $\mathrm{X}$ & $\mathrm{X}$ & $\mathrm{X}$ & $\mathrm{X}$ & $\mathrm{X}$ \\
\hline 3 & 3 & $85-100$ & $21.85-22.80$ & 13.7 & $\mathrm{X}$ & $\mathrm{X}$ & $\mathrm{X}$ & $\mathrm{X}$ & $\mathrm{X}$ \\
\hline 6 & 4 & $90-105$ & $50.40-50.55$ & 16.1 & $\mathrm{x}$ & $\mathrm{X}$ & $\mathrm{x}$ & $\mathrm{x}$ & $\mathrm{x}$ \\
\hline 8 & 3 & $0-15$ & $67.00-67.15$ & 13.1 & - & - & $\mathrm{X}$ & $\mathrm{X}$ & - \\
\hline 10 & 3 & $90-105$ & $85.90-86.05$ & 10.4 & $\mathrm{X}$ & $\mathrm{X}$ & $\mathrm{X}$ & $\mathrm{X}$ & $\mathrm{X}$ \\
\hline 12 & 4 & $135-150$ & $105.85-106.00$ & - & - & - & - & - & $\mathrm{X}$ \\
\hline 14 & 3 & $90-105$ & $121.90-122.05$ & 90 & $\mathrm{X}$ & $\mathrm{X}$ & $\mathrm{X}$ & $X$ & $\mathrm{X}$ \\
\hline 16 & 3 & $90-105$ & $140.90-141.05$ & $\ldots$ & - & - & - & - & $\mathrm{x}$ \\
\hline 20 & 3 & $135-150$ & $179.35-179.50$ & 11.9 & $\mathrm{X}$ & $\mathrm{X}$ & $\mathrm{X}$ & $\mathrm{X}$ & $\mathrm{X}$ \\
\hline 23 & 4 & $75-90$ & $208.25-208.40$ & - & - & - & - & - & $\mathrm{X}$ \\
\hline 26 & 2 & $45-60$ & $231.95-232.10$ & 19.9 & $\mathrm{X}$ & $\mathrm{X}$ & $\mathrm{X}$ & $\mathrm{X}$ & $\mathrm{X}$ \\
\hline
\end{tabular}

solution was treated as described below.

Total Sediment. Approximately 25 to 30 grams of wet sediment was hydrolyzed by refluxing (with magnetic stirring) in $6 \mathrm{M} \mathrm{HC1}$ for twenty-four hours. After hydrolysis the insoluble residue was separated by centrifuging.

Foraminiferal Fraction. Approximately 50 grams of wet sediment was slurried in 300 to $500 \mathrm{ml}$ of distilled water and poured onto a carefully cleaned $0.062 \mathrm{~mm}$ stainless steel sieve. The collected foraminifera were washed thoroughly with deionized water followed by doubly distilled water and treated for two ten minute periods with ultrasonic vibration to remove attached or included clay particles. The cleaned foraminifera were dissolved in $50 \mathrm{ml}$ $6 \mathrm{M} \mathrm{HCl}$ and the solution was hydrolyzed for twenty-four hours.

Desalting procedure. The $\mathrm{HC} 1$ solutions were evaporated to dryness under reduced pressure (the free acid at room temperature), and the residue was dissolved in 5 to 10 $\mathrm{ml}$ of distilled water and desalted as described above. The desalting columns were eluted with 400 to $500 \mathrm{ml}$ of $1.5 \mathrm{M}$ $\mathrm{NH}_{4} \mathrm{OH}$, and the effluent was evaporated under reduced pressure at $50^{\circ} \mathrm{C}$ to a volume of approximately $20 \mathrm{ml}$ (some samples required a filtration at this point to remove inorganic solids which has precipitated). The final evaporation was accomplished under vacuum in a dessicator.

\section{RESULTS AND DISCUSSION}

Results of the various analyses are summarized in Figure 1 , in which the alleu/iso ratios in the "free", "peptide", and "residue" fractions; the total sediment; and the foraminiferal fraction are plotted as a function of depth.

Analysis of the data in Figure 1 shows a striking difference in the rate of racemization (increasing ratio of alleu to iso) between the residue fraction and the acidextracted soluble amino acids, and between the total sediment and foraminiferal fractions. The following conclusions can be drawn from analysis of the data:

1) Considerable material remains after free acid and other HC1-soluble material has been removed. The racemization in this residue fraction is slow and almost linear with depth (and age). This slow racemization resembles that found in the protein component isolated from calcareous sediments. The alleu/iso ratio in the protein component of a sediment 2 m.y. old was found to be 0.11 (Bada and Schroeder, 1972). Thus, the alleu/iso = 0.15 for section 26-3 indicates a probable age of 3 m.y.

The close relationship between the ratios obtained for the residue fraction with those obtained by hydrolysis of the total (unfractionated) sediment indicates that the bulk of the amino acids in this sediment are in the form of $\mathrm{HCl}$-insoluble material (protein ?). This material may be associated with the clay, which is the major inorganic component in this core.

2) The alleu/iso ratios of the foraminiferal fraction are intermediate between the hydrolyzed fraction ( $\mathrm{HCl}$. extracted amino acids and peptides) and the residue fraction, which indicates that a significant portion of the amino acids associated with the foraminifera are in the form of proteins and therefore remain in the $\mathrm{HC} 1$-insoluble fraction. With increasing age (depth of burial), the alleu/iso ratios in the foraminiferal tests approach that in the hydrolyzed $\mathrm{HC} 1$ soluble fraction. This indicates that the amount of protein present in the tests decreases with age. This is in agreement with the studies of Bada and Schroeder (1972), who showed that in calcareous sediments the amino acids are initially in the form of proteins, but these proteins are gradually hydrolyzed with time producing smaller peptides and free amino acids.

3) The variability of the calcium carbonate content of the various core sections (see Table 1) causes slight discontinuities in the alleu/iso ratios observed in the total sediment analyses. These discontinuities arise because the isoleucine in the foraminiferal tests is more highly racemized than that in the bulk sediment. Therefore, higher carbonate concentrations cause larger than expected ratios in the total sediment hydrolyses.

4) The kinetics of racemization of isoleucine in this core are similar to those observed in other deep-sea sediments (Bada, et al., 1970; Wehmiller and Hare, 1971; Bada and Schroeder, 1972). The racemization reaction can be written as

$$
\text { L-isoleucine } \frac{k_{\text {iso }}}{k_{\text {alleu }}} \text { D-alloisoleucine }
$$




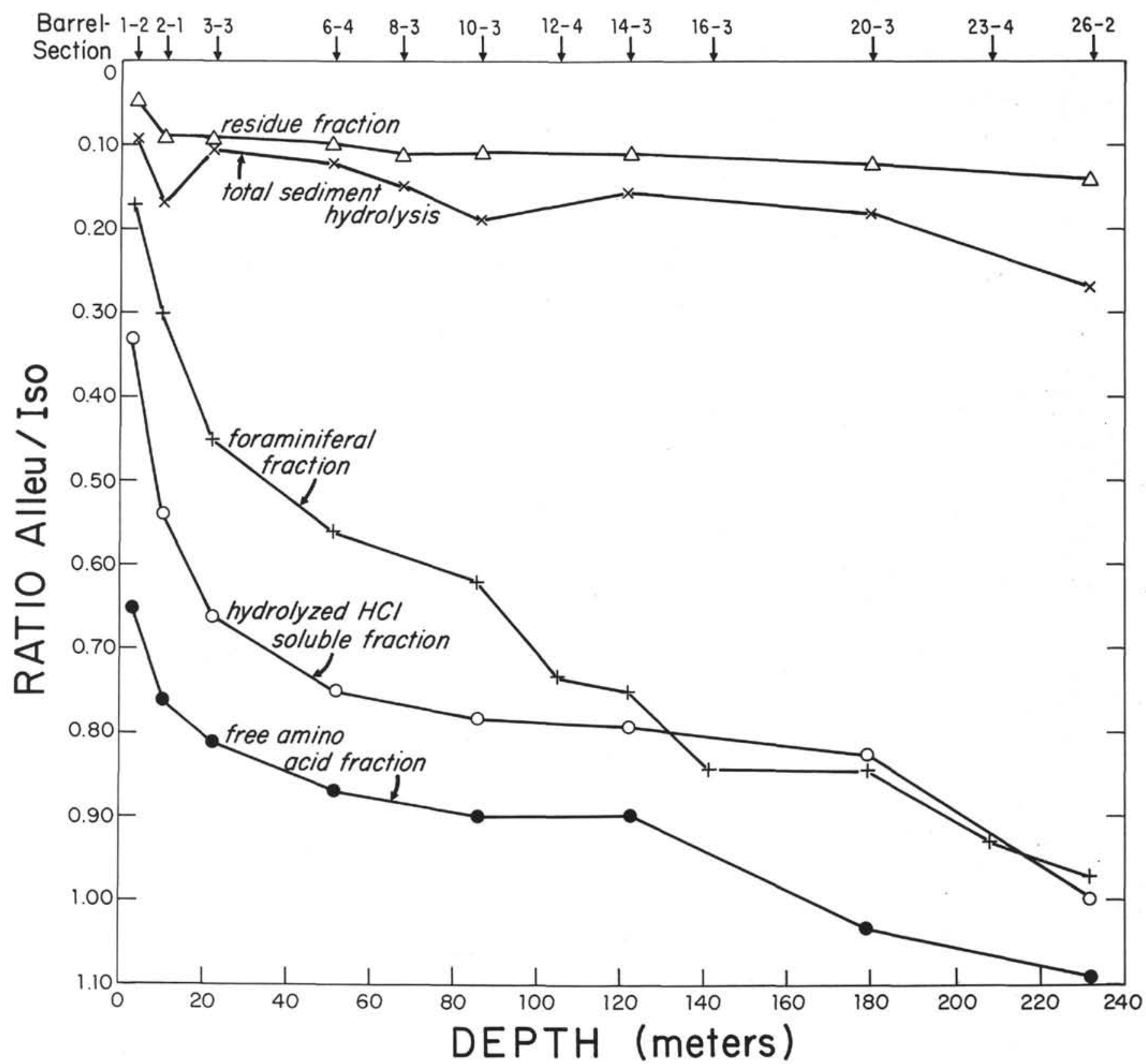

Figure 1. Racemization of isoleucine as a function of depth in cores from the Deep-Sea Drilling Project Leg 15, Site 148.

where $k_{\text {iso }}$ and $k_{\text {alleu }}$ are the first order rate constants for interconversion of isoleucine and alloisoleucine, respectively. The integrated rate expression for this reaction is (see Bada and Schroeder, 1972 for derivation)

$$
\begin{aligned}
& \text { Ln }\left[\frac{1+(\text { alleu/iso })}{1,-0.725(\text { alleu/iso })}\right] \\
& =1.72 \cdot k_{\text {iso }} \cdot t \\
& =1.72 \cdot k_{\text {iso }}^{\prime} \cdot \text { idepth of burial in } \\
& \text { sedimentary column })
\end{aligned}
$$

Figure 2 shows a plot of the data in the form of equation (2). Previous investigations (Wehmiller and Hare, 1971; Bada and Schroeder, 1972) have shown that plots of

$$
\operatorname{Ln}\left[\frac{1+(\text { alleu/iso })}{1-0.725(\text { alleu/iso })}\right]
$$

versus age are linear only up to alleu/iso $=0.3$ to 0.4 . For ratios greater than this, the plots show a gradual decrease in slope. This trend can be seen in Figure 2 for the foraminiferal, hydrolyzed $\mathrm{HC} 1$-soluble, and free amino acid fractions. However, the plots for the residue fraction and total sediment are nearly linear with depth. Linear kinetics are similarly observed for the racemization of isoleucine in collagen, the fiberous protein found in bones (Bada, 1972). This suggests that the residue fraction is probably composed mainly of protein-like material.

5) Estimates of the rate of sedimentation can be made from the extent of isoleucine racemization. However, the 


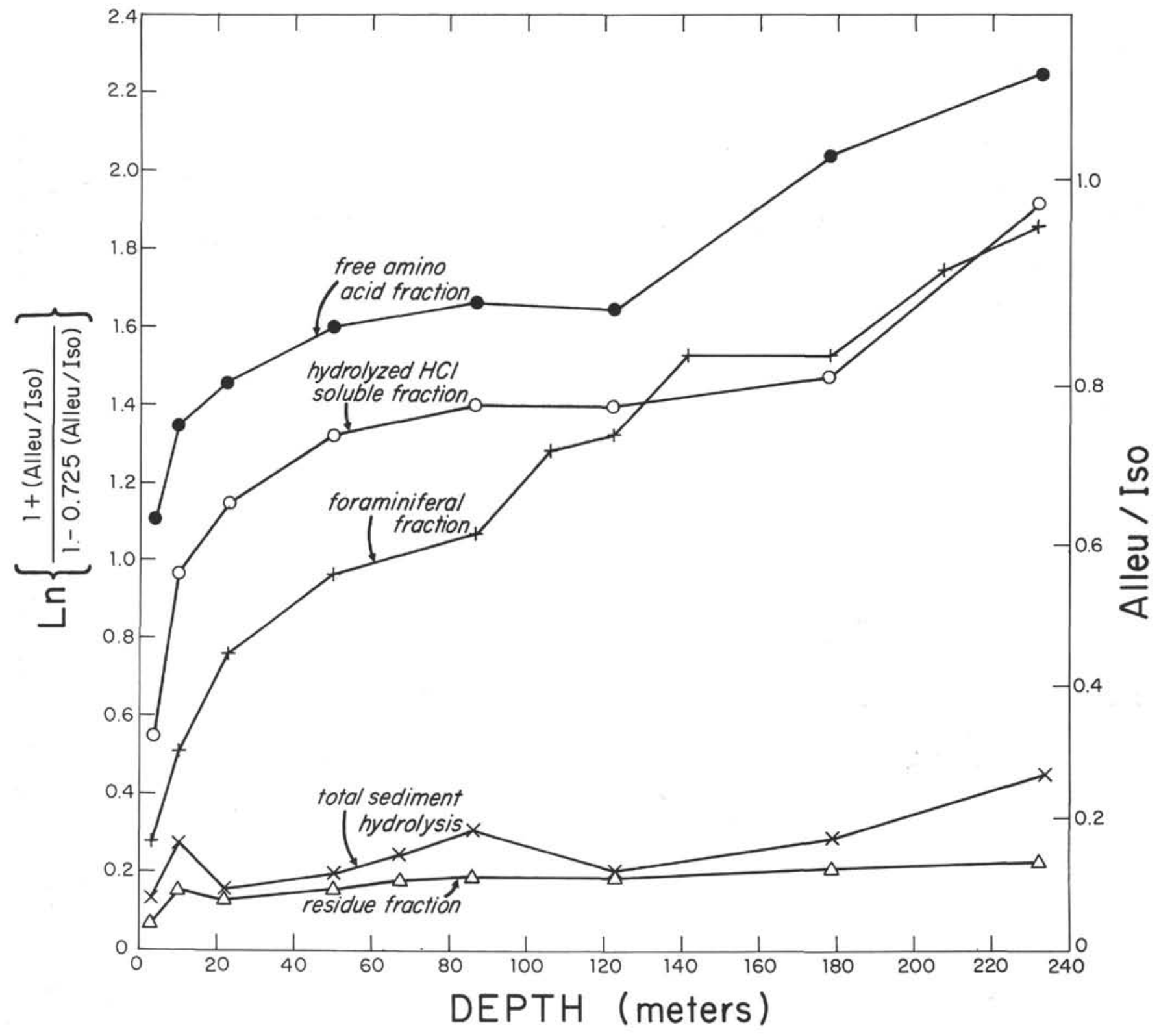

Figure 2. Kinetics of racemization of isoleucine in cores from Leg 15, Site 148.

rate of racemization of isoleucine has so far only been studied in detail in calcareous sediments (Bada and Schroeder, 1972). Also, as indicated above, equation (2) can only be used to calculate ages for sediments with ratios less than 0.3 to 0.4 . Thus, in the present study, age calculations are limited to the top two foraminiferal fractions. The present bottom water temperature in the area in the Caribbean Sea where this core was recovered is $5^{\circ} \mathrm{C}$. The value of $\mathrm{k}_{\text {iso }}$ at this temperature is $2.6 \times 10^{-6}$ $\mathrm{yr}^{-1}$ (Bada and Schroeder, 1972). Using this rate constant in equation (2), and the alleu/iso ratios determined in the foraminiferal fraction of Section 1, Core 2 and Section 2, Core 1, yields ages of 64,000 and 125,000 years, respectively. Based on these ages, sedimentation rates of 3.8 $\mathrm{cm} / 10^{3} \mathrm{y}$ and $8.0 \mathrm{~cm} / 10^{3} \mathrm{y}$ are calculated. This yields an average sedimentation rate of $5.9 \mathrm{~cm} / 10^{3} \mathrm{y}$ for the top portion of this core, which compares favorably with estimates ranging from $4.5 \mathrm{~cm}$. to $8.0 \mathrm{~cm} / 10^{3} \mathrm{y}$ derived by paleontological examination of the core (N. T. Edgar, private communication).

\section{CONCLUSIONS}

The separation and analyses of the free amino acid, peptide, residue, and foraminiferal fractions has been carried out in a single continuous core. The relative rates of isoleucine in the various forms, i.e., free $>$ peptide $>$ residue, is similar to that found in other deep-sea sediments (Bada and Schroeder, 1972). The slow rate of racemization found in the residue fraction is consistent with the mechanism proposed by Bada and Schroeder (1972), which would predict that since this fraction is probably composed mainly of proteinaceous material, the amino acids in these 
proteins would undergo only very slow racemization. The major difference in the racemization of isoleucine in this core compared to that in calcareous sediments is that in the latter, protein material is nearly completely hydrolyzed to free amino acids and small peptides in less than a million years, while in this core, protein material contains the bulk of the amino acids even at the bottom of the core, which likely has an age in excess of 3 million years.

Further studies on this essentially noncalcareous core are in progress to determine whether the racemization of isoleucine in the residue fraction can be used in geochronology. At present, the reaction can only be used to date calcareous cores with ages less than about 300,000 years. Using the alleu/iso ratio in the residue fraction, it may be possible to extend the region of applicability of the reaction, possibly to several million years. These results will be reported in subsequent publications.

\section{ACKNOWLEDGMENTS}

E. H. M. was partially supported by NASA Grant NGL 10-007-010, a University Sustaining Program at the University of Miami. Acknowledgment is made to the donors of the Petroleum Research Fund, administered by the American Chemical Society, for support of this research. The amino acid analyzer was obtained through
Grant GA-31498 from the Oceanography Section of the National Science Foundation.

\section{REFERENCES}

Bada, J. L., 1971. Kinetics of the non-biological decomposition and racemization of amino acids in natural waters. In Nonequilibrium Systems in Natural Water Chemistry. J. D. Hem, Ed., Advances in Chemistry Series No. 106 (American Chemical Society, Washington, D. C.), 309.

, 1972. The dating of fossil bones using the racemization of isoleucine. Earth and Planetary Science Letters. 15, 223.

Bada, J. L. and Schroeder, R. A., 1972. Racemization of isoleucine in calcareous marine sediments: kinetics and mechanism. Earth and Planetary Science Letters 15, 1.

Bada, J. L., Luyendyk, B. P. and Maynard, J. B., 1970. Marine sediments; dating by the racemization of amino acids. Science. 170, 730 .

Turekian, K. K. and Bada, J. L., 1972. The dating of fossil bones. In Calibration of Hominoid Evolution, W. W. Bishop, J. A. Miller and S. Cole, Eds. (Scottish Academic Press, Edinburgh). 171.

Wehmiller, J. F. and Hare, P. E., 1971. Racemization of amino acids in marine sediments. Science 173, 907. , 1972. Amino acid content of some samples from the deep sea drilling program. In Hays, J. D. et al. 1972 , Initial Reports of the Deep Sea Drilling Project, Volume IX. Washington (U. S. Government Printing Office), 903. 